\title{
Sağlık Çalışanı Gözüyle Hizmet Kalite Standartlarının Etkinliğinin Değerlendirilmesi
}

\author{
Evaluation of the Effectiveness of Service Quality Standards with Eyes of Health \\ Employee
}

\author{
Yeliz DOĞAN MERİH ${ }^{\mathrm{a}}$ Pınar GÜNGÖR ${ }^{\mathrm{b}}$, Meryem YAŞAR KOCABEY ${ }^{\mathrm{b}}$, \\ Ayşegül SAMATLI ${ }^{\mathrm{b}}$, Çiğdem EMUCE ${ }^{\mathrm{b}}$, Hülya EKSAN ${ }^{\mathrm{b}}$, Şebnem ÖZDEM ${ }^{\mathrm{c}}$
}

\begin{abstract}
ÖZET Amaç: Kapsamlı ve sistematik standartların, bölümler bazında oluşturulmuş kriterlerinin sağlık çalışanları tarafindan olumlu ve olumsuz yönlerinin değerlendirilmesini, iyileştirici önerilerin belirlenmesini sağlamak amacıyla bu çalışma gerçekleştirilmiştir. Yöntem: Çalışma, 2012 yılı içerisinde bir özel dal eğitim ve araştırma hastanesinde Hizmet Kalite Standartları (HKS) ve bu yönde gerçekleştirilen denetimlere yönelik sağlık çalışanlarının görüşlerini belirlemek amacıyla tanımlayıcı olarak yürütülmüsşür. Araştırmanın örneklemini, araştırmaya katılmayı kabul eden ve HKS gereğince tüm bölümleri karşılayan 30 sağlık çalışanı oluşturmuş̧ur. Veriler araştırmacılar tarafindan oluşturulan anket formunun yine alanda yetkin araştırmacilar tarafindan katılımcılarla birebir yapılan kapsamlı odak grup görüşmesi sonrasında doldurulması ile toplanmış̧ır. Elde edilen veriler SPSS programı ile yüzdelik olarak değerlendirilmiştir. Bulgular: Katılımcıların çalıştıkları birimlerin kriterlerine yönelik, spesifik analizlerinin ortak yönleri değerlendirildiğinde; HKS'nin olumlu yönleri içerisinde, ortak dil ve standartların oluşturulması, hasta ve çalışan güvenliği uygulamalarının şekillenmesi ve kullanılması, risk oranlarının azaltılması, önleyici uygulamaların aktifleşmesi, kayıt güvenliği sağlanarak sağlık alanına yönelik etkin bir değerlendirme ortamı oluşturulması ifadelerinin ağrılıklı yer aldığı saptanmıştır. HKS'nin olumsuz yönleri arasında ise çok benzer ve tekrarlı kayıtların oluşturulması bu nedenle zaman yönetiminde aksama, denetimler sırasında sadece belirli meslek gruplarına (hemşire ağıllıklı) yönelik denetimlerin gerçekleştirilmesi bu nedenle standartların tüm meslek gruplarınca benimsenme oranının azalması, fazla maliyet oranları, denetimler sonrasında bazı kriterlere yönelik yaşanan sıkıntılarla ile ilgili geribildirim mekanizmasının aktif hale dönüştürülmemesi, standartların iyileştirilmesi için çalışanların görüşlerinin alınmaması gibi ifadeler yer almıştır. Sonuç: Sağlık çalışanlarının HKS uygulamalarını değerlendirmek için verdikleri puanların dağılımına baktığımızda, \%75,3 oranıyla uygulamaların etkinliğini iyi olarak nitelendirmişler ve uygulamalara ait memnuniyetlerini ifade etmişlerdir.
\end{abstract}

Anahtar kelimeler: Hizmet Kalite Standartları, Sağlık Çalışanları, Değerlendirme

\begin{abstract}
Aim: Main aim is; partitions created on the basis of criteria positive-negative evaluation by health workers and determination of remedial proposals. Methods: Our study was carried out to, teaching and research hospital in 2012 in a special branch of the Service Quality Standards and to determine the opinions of health employments for controls. The study sample, formed by 30 health workers. The data, generated to fill the questionnaire by researchers and filling was collected after the one on one group interviews with the participants. The obtained, evaluated percentage with the program SPSS. Results: The participants specific analysis on the criteria of their departments was evaluated; the following statements were the most common ones: The service quality standards positive impacts; A common language was created, standards were determined, it lead to shape and use of the patience and health care workers security applications, it decreased the percentage of the risk and activated preventive applications. The service quality standards enabled us to carry out effective evaluations and provided the registration safety. The negative impacts of the service quality standards; The time management was disrupted by the similar and repetitive registrations, the standards were not internalized by all of the occupational groups since the inspections only were held towards the nurses, it has high cost ranges, after the inspections the feedback mechanism was not activated on some criteria's problematic sides, the opinions of the ones who are working to improve the standards was not taken. Conclusion: When the distribution of the points was checked, it has seen that $75,3 \%$ of the health care workers said the service quality standards application is useful and they are content with the application.
\end{abstract}

Key Words: Service quality standards, health workers, evaluations.

\footnotetext{
${ }^{1}$ Dr., Zeynep Kamil Kadın ve Çocuk Hastalıkları Eğitim ve Araştırma Hastanesi, yelizmrh@ gmail.com , Gsm: 05445219151

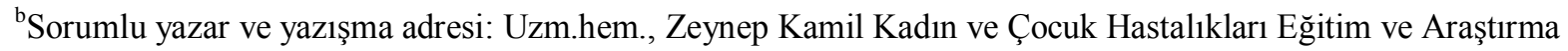

Hastanesi, p_gungor18@hotmail.com

c Odm., Zeynep Kamil Kadın ve Çocuk Hastalıkları Eğitim ve Araştırma Hastanesi, zkhkalite@ gmail.com Geliş Tarihi:17/12/2014 Kabul Tarihi:28/01/2015.

*Çalışma 02-04 Mayıs 2013 tarihinde Ankara'da düzenlenen IV. Uluslararası Sağlıkta Performans ve Kalite Kongresinde sözlü bildiri olarak sunulmuştu
} 


\section{Giriș}

Tıp bilimin ve teknolojinin zaman içinde sürekli gelişmesi ve sağlık profesyonellerinin bu gelişmeler doğrultusunda hizmet sunmayı istemeleri, insan yaşamı ile direkt ilgili olan sağlık hizmetlerinde sifir hatanın ya da en az hatanın olmasının gerekliliğini gündeme getirmiştir. Sağlık kuruluşlarının performanslarının yükseltilmesi için sağlık hizmetlerinden yararlanacak bireylerin beklentilerinin karşılanması gibi gereklilikler dünya genelinde, sağlık kuruluşlarında kaliteli hizmet sunumunun gelişmesini sağlamıştır. ${ }^{1}$

Dünyada çeşitli ülke örnekleri incelendiğinde, sağlık hizmetlerinin kalitesinin artırılmasına yönelik yapılan çalışmaların artık daha çok ulusal kalite ve akreditasyon sistemleri üzerinden yürütülmekte olduğu görülmektedir. Çünkü ülkelerin sağlı sistemlerinin ihtiyaçları, öncelikleri, farklı beklentileri ve uluslararası akreditasyon sistemlerinin getirdiği mali yük gibi sebepler dünyada pek çok ülkenin sağlikta ulusal bir kalite sistemi kurmasına sebep olmuştur. ${ }^{2,3}$

Ülkemizde 2003 yılında Sağlıkta Dönüşüm Programı ile kalite hizmet sunumu çalışmaları başlamıştır. Ülkemize özgü ilk ulusal standart HKS'dir. HKS çalışmaları, 2003 yılında Sağlık Bakanlığ 1 tarafindan başlatılmış ve 2005 ilk set hali oluşturulmuş, 2011 yılından itibaren ise ülkemizdeki tüm hastanelerde kullanılmaya başlanmıştır. ${ }^{4}$ Türkiye'de 2011 yılında yürürlüğe giren Kurum Performans ve Kalite Yönergesi ile tüm hastaneler HKS'yi uygulamaya ve hastaneler Hizmet Kalite Belgesiyle belgelendirmeye başlanmıştır. $\mathrm{Bu}$ yönergenin amacı, sağlık hizmetlerinin iyileştirilmesi, kaliteli ve verimli sağlık hizmet sunumunun sağlanması için sağlık kurum ve kuruluşlarının kurumsal performansının ölçülmesine yönelik olarak

\section{Gereç ve Yöntemler}

Çalışmamız, 2012 y1lı içerisinde bir özel dal eğitim ve araştırma hastanesinde ölçülebilir ve karşılaştırılabilir performans, kalite ve diğer kriterler ile hizmet sunum şartlarının belirlenmesi, halkın görüşlerinin bu sürece yansitılması suretiyle kurumsal performans katsayısının tespitine ve hizmet sunumu açısından belgelendirilmesine ilişkin usul ve esasları düzenlemektir. ${ }^{5}$

Hastanelerde yürütülen kalite çalışmalarının başarısı çalışanların katılımı ve desteği ile yakından ilişkilidir. Çalışan katılımının yüksek olduğu kurumlarda, kalite iyileştirme sürecinde istendik sonuçlara ulaşma ve kalite kültürünün oluşması daha kısa zamanda gerçekleşir. Günümüzde çalışanlar, kendilerini ilgilendiren her türlü kararın görüşülmesine ve sonuçlandırılmasına aktif olarak katılıp, düşüncelerini ifade etmek, bu konularda fikirlerinin alınmasını talep etmektedirler. $\mathrm{Bu}$ nedenle, katılımı, yetki devrini, kişisel ve örgütsel gelişmeyi teşvik eden bir ortamın oluşturulması ve kaliteyi destekleyen ödül sistemlerinin benimsenmesi, çalışanların tüm potansiyel yeteneklerinden yararlanma ve geliştirmeye yönelik bir yönetim tarzı belirlenmelidir. ${ }^{6}$

Temelinde hasta ve çalışan güvenliği olan hizmet kalite standartları içerisinde sağlık hizmetinde rol alan iç müşterilerin ve faydalanan dış müşterilerin düşüncelerinin ve memnuniyetinin esas alınması önemlidir. Memnuniyet ve beklenti değerlendirmeleri hastanenin ve performansın ölçümü bakımından büyük önem arz etmektedir. Sağlık hizmetlerinin sunum tarzının ancak hizmet sürecine katkıda bulunan çalışanlar ve hizmeti alan hastalardan gelen görüşler çerçevesinde şekillendirilebileceği bir gerçektir. ${ }^{7}$

Çalışmamı bölümler bazında oluşturulmuş kriterlerinin sağlık çalışanları tarafından olumlu ve olumsuz yönlerinin değerlendirilmesini, iyileştirici önerilerin belirlenmesini sağlamak amacıyla gerçekleştirilmiştir.

Hizmet Kalite Standartları ve bu yönde gerçekleştirilen denetimlere yönelik sağlık çalışanlarının görüşlerini belirlemek amacıyla tanımlayıcı olarak yürütülmüştür. 
Araştırmanın örneklemini, araştırmaya katılmayı kabul eden ve Hizmet Kalite Standartları gereğince tüm bölümleri karşılayan 30 sağlık çalışanı oluşturmuşstur. Katılımcıların seçiminde dikkat edilen nokta; HKS kriterlerinin dört boyutunu kapsayan "Kurumsal Hizmet Yönetimi, Sağlık Hizmeti Yönetimi, Destek Hizmeti Yönetimi ve İndikatör Yönetimi” sürecinde yer alan tüm bölümlerin hizmet sunumunda çalışan 1 yönetici, en az bir çalışanın bu grup içerisinde olmasıdır.

\section{Bulgular}

Araştırma kapsamına alınan sağlık çalışanlarının \%36.7'sinin 24-30 yaş gurubunda yer aldığ 1 , \%80'inin lisans ve
Veriler katılımciların sosyodemografik özelliklerini, hasta ve çalışan güvenliği uygulamaları konusundaki görüşlerini, HKS değerlendirme görüşlerini, hata bildirimine yönelik görüşlerini belirlemeye yönelik 20 soruluk anket formu ile toplanmıştır. Anket formları alanda yetkin araştırmacılar tarafından katılımcılarla sürecin etkin bir şekilde değerlendirilmesi için birebir yapılan kapsamlı odak grup görüşmesi sonrasında doldurulmuştur. Elde edilen veriler SPSS programı ile yüzdelik olarak değerlendirilmiştir.

üzeri eğitim aldığı, \%33.4'ünün hemşire olduğu, HKS gereğince tüm bölümlerden katılımın sağlandığ 1 belirlenmiştir.

\section{Tablo 1. Katılımcıların hasta ve çalışan güvenliğine yönelik tanımları}

\begin{tabular}{|c|c|c|}
\hline HASTA GÜVENLİĞİ NEDİR? & Sayı & $\%$ \\
\hline $\begin{array}{l}\text { Hasta güvenliği; sağlık çalışanlarının hasta bakımı uygulamalarına } \\
\text { destek olmak ve kolaylı sağlamak amacıyla yapılan uygulamaların } \\
\text { tamamı }\end{array}$ & 5 & 16,4 \\
\hline $\begin{array}{l}\text { Hasta güvenliği; sağlık hizmetlerinin kişilere vereceği olası zararı } \\
\text { önlemek amacıyla alınan önlemlerin tamamı }\end{array}$ & 22 & 73,6 \\
\hline $\begin{array}{l}\text { Hasta güvenliği; hastaların kendilerine zarar gelmemesi için aldıkları } \\
\text { önlemlere sağlık çalışanları tarafından destek olunması }\end{array}$ & 3 & 10,0 \\
\hline ÇALIŞAN GÜVENLİĞİ NEDİR? & Sayı & $\%$ \\
\hline $\begin{array}{l}\text { Çalışan güvenliği; sağlık çalışanlarının göreceği zararı önlemek } \\
\text { amacıyla sağlık kuruluşları ve bu kuruluşlardaki çalışanlar } \\
\text { tarafindan alınan önlemler }\end{array}$ & 21 & 70.0 \\
\hline $\begin{array}{l}\text { Çalışan güvenliği; sağlık çalışanlarının uygulamalarında kolaylık } \\
\text { sağlamak amacıyla yapılan uygulamaların tamamı }\end{array}$ & 3 & 10,0 \\
\hline $\begin{array}{l}\text { Çalışan güvenliği; çalışanların kendilerine zarar gelmemesi için aldıkları } \\
\text { önlemlere kurum politikalarının destek olması }\end{array}$ & 6 & 20,0 \\
\hline Toplam & 30 & 100,0 \\
\hline
\end{tabular}

Kat1lımc1ların \%73,6's1 temelde hasta güvenliğini sağlı hizmetlerinin kişilere vereceği zararı önlemek ve $\% 70$ oranında çalışan güvenliğini, çalışanlara gelebilecek zararı önlemek olarak tanımladıkları saptanmıştır (Tablo 1).Katılımcılar hasta ve çalışan güvenliğgine ait rolerini tanımlarken $\% 66,6$ oranında sürecin tamamında rolleri olduğunu ifade etmişlerdir (Tablo 2).
Çalışmada katılımcılar daha önce kısmi olarak bulunan ama HKS ile daha da şekillenen hasta güvenliği uygulamalarını 8 başlık altında toplamışlar ve en fazla $\% 30$ ile kimliklendirmeyi birinci sırada, $\% 18$ ile ilaç güvenliğini ikinci sırada ve $\% 17$ ile enfeksiyon kontrolünü üçüncü sırada belirtmişlerdir (Grafik 1). 
Tablo 2. Katılımcıların hasta ve çalışan güvenliğine yönelik rolleri

\begin{tabular}{lcc} 
HASTA VE ÇALIŞAN GÜVENLIĞİ ROLLERİ & Sayı & $\%$ \\
\hline $\begin{array}{l}\text { Hasta ve çalşanan güvenliğine ait riskleri belirleyen, önlemeye } \\
\text { yönelik uygulamalarını planlayan, uygulayan ve değerlendiren }\end{array}$ & $\mathbf{2 0}$ & $\mathbf{6 6 . 6}$ \\
$\begin{array}{l}\text { Oluşturulmuş hasta ve çalışan güvenliği uygulamalarının } \\
\text { gerçekleştirilmesine destek olan }\end{array}$ & 10 & 33,4 \\
Toplam & $\mathbf{3 0}$ & $\mathbf{1 0 0 , 0}$ \\
\hline
\end{tabular}

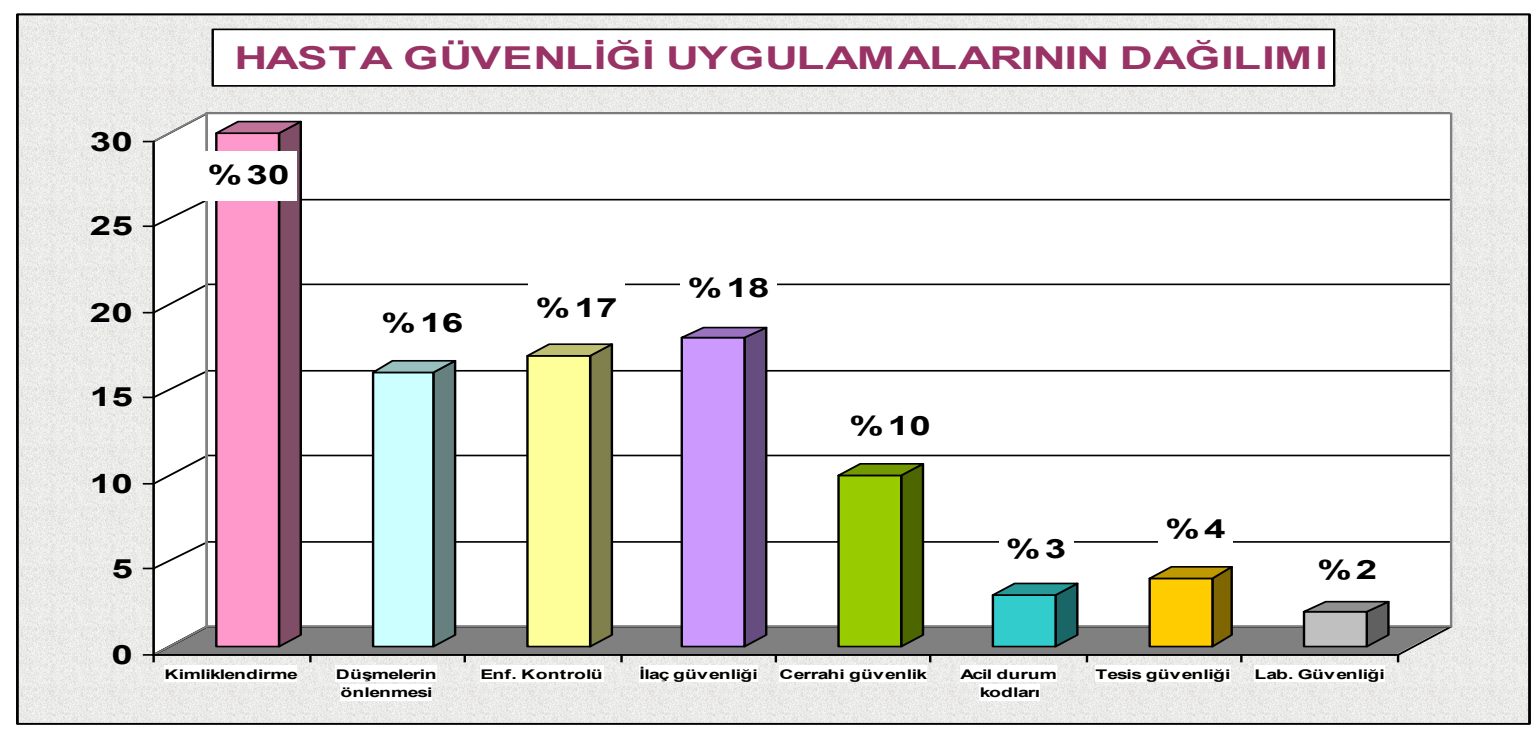

Grafik 1. Katılımcıların hastanelerinde uygulanan hasta güvenliği uygulamalarına yönelik görüşleri

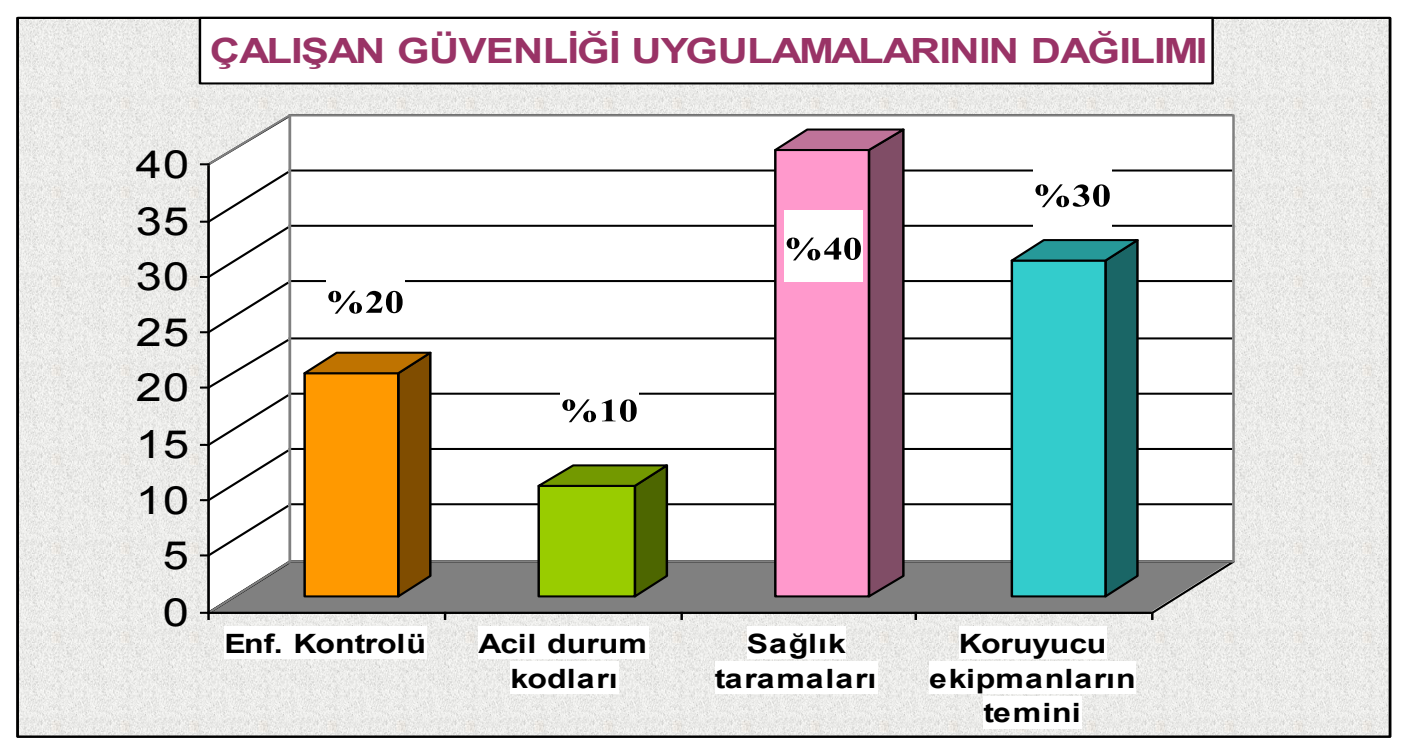

Grafik 2. Katılımcıların hastanelerinde uygulanan çalışan güvenliği uygulamalarına yönelik görüşleri

Çalışmada katılımcılar daha önce kısmi olarak bulunan ama HKS ile daha da şekillenen çalışan güvenliği uygulamalarını 4 başlık altında toplamışlar ve en fazla
\%40 ile sağlık taramalarını birinci sırada, $\% 30$ ile koruyucu ekipmanların teminini ikinci sirada ve $\% 20$ ile enfeksiyon kontrolünü üçüncü sirada belirtmişlerdir (Grafik 2). 
Tablo 3. HKS'nın hasta ve çalışan güvenliğine getirileri

\begin{tabular}{|c|c|c|}
\hline HASTA VE ÇALIŞAN GÜVENLİĞİNE GETİRILERİ & Sayı & $\%$ \\
\hline $\begin{array}{l}\text { Hizmet kalite standartları bölümümüz hasta ve çalışan güvenliği } \\
\text { uygulamalarının şekillenmesinde, standartlarının belirlenmesinde ve aktif } \\
\text { uygulanmasında faydalı oldu }\end{array}$ & 20 & 66.6 \\
\hline $\begin{array}{l}\text { Hizmet kalite standartları bölümümüz hasta ve çalışan güvenliği } \\
\text { uygulamalarının var olan prosedürlerinin uygulanmasına yardımcı oldu }\end{array}$ & 1 & 3,4 \\
\hline $\begin{array}{l}\text { Hizmet kalite standartları bölümümüz mevcut hasta ve çalışan güvenliği } \\
\text { uygulamalarının eksik yanlarını görmemizi ve tamamlamamızı sağladı }\end{array}$ & 9 & 30,0 \\
\hline Toplam & 30 & 100,0 \\
\hline
\end{tabular}

Katılımc1lar HKS'nin hasta ve çalışan güvenliğine genel olarak getirilerini, \%66.6 oran1 ile "HKS bölümümüz hasta ve çalışan güvenliği uygulamalarının şekillenmesinde, standartlarının belirlenmesinde ve aktif uygulanmasında faydalı oldu" şeklinde ifade etmişlerdir (Tablo 3).

Tablo 4. HKS'nın çalışan gözüyle olumlu ve olumsuz yönleri

\begin{tabular}{lcc}
\hline HKS OLUMLU YÖNLERİ & Sayı & $\%$ \\
\hline Ortak dil ve Standartların oluşturulmasını sağladı & 19 & 25.0 \\
Hasta ve çalışan güvenliği uygulamalarının şekillenmesini ve & 25 & 33.0 \\
kullanılmasını sağladı & & \\
Risk oranlarının azaltılmasını sağladı & 8 & 10.5 \\
Önleyici uygulamaların aktifleşmesi sağlandı & 7 & 9.2 \\
Sağlık alanına yönelik etkin bir değerlendirme ortamı oluşturuldu & 11 & 14.5 \\
Kayıt güvenliği sağladı & 6 & 7.8 \\
Toplam & $76^{*}$ & 100.0 \\
\hline HKS OLUMSUZ YÖNLERİ & Sayı & $\%$ \\
\hline Benzer ve tekrarlı kayıtların oluşturulması bu nedenle zaman & 28 & 34,6 \\
yönetiminde aksama & & 15 \\
Denetimler sirasında sadece belirli meslek gruplarına (hemşire & 15 & 18.5 \\
ağırlıklı) yönelik denetimlerin gerçekleştirilmesi bu nedenle & & \\
standartların tüm meslek gruplarınca benimsenme oranının azalması & & 12.4 \\
Fazla maliyet oranları & 10 & 18.5 \\
$\begin{array}{l}\text { Denetimler sonrasında bazı kriterlere yönelik yaşanan sıkıntılarla ile } \\
\text { ilgili geribildirim mekanizmasının aktif hale dönüştürülmemesi }\end{array}$ & 15 & 16.0 \\
Standartların iyileştirilmesi için çalışanların görüşlerinin alınmaması & 13 & \\
Toplam & $81^{*}$ & 100.0 \\
\hline * Birden fazla seçenek belirtilmiştir. & &
\end{tabular}

Çalışmada katılımcılar HKS'nin genel olarak değerlendirmesini yapmışlar ve HKS'nin bölümlerine ait kriterleri baz alarak olumlu ve olumsuz yönlerini ifade etmişlerdir. HKS'nın olumlu yönleri içerisinde \%33 oranı ile "Hasta ve çalışan güvenliği uygulamalarının şekillenme- sini ve kullanılmasını sağladı" ilk sırada yer almıştır, bunu standartları oluşturdu, etkin değerlendirme ortamı sağladı, riskleri azalttı ifadeleri izlemiştir.

HKS'nın olumsuz yönleri içerisinde ise \%34,6 oranı ile "Benzer ve tekrarlı kayıtların oluşturulması bu 
nedenle zaman yönetiminde aksama" ilk sırada yer almıştır, bunu sadece belirli meslek gruplarının (ağırlıklı hemşireler) denetlenmesi, denetim kriterleri ve denetim süreci ile ilgili geribildirim mekanizmasının yetersiz olması ifadeleri izlemiştir (Tablo 4). Sağlık çalışanlarının
HKS uygulamalarını değerlendirmek için verdikleri puanların dağılımına baktığımızda, $\quad \% 76,7 \quad$ oraniyla uygulamaların etkinliğinin iyi olarak nitelendirildiği ve uygulamalara ait memnuniyetlerinin iyi olduğu belirlenmiştir (Grafik 3).

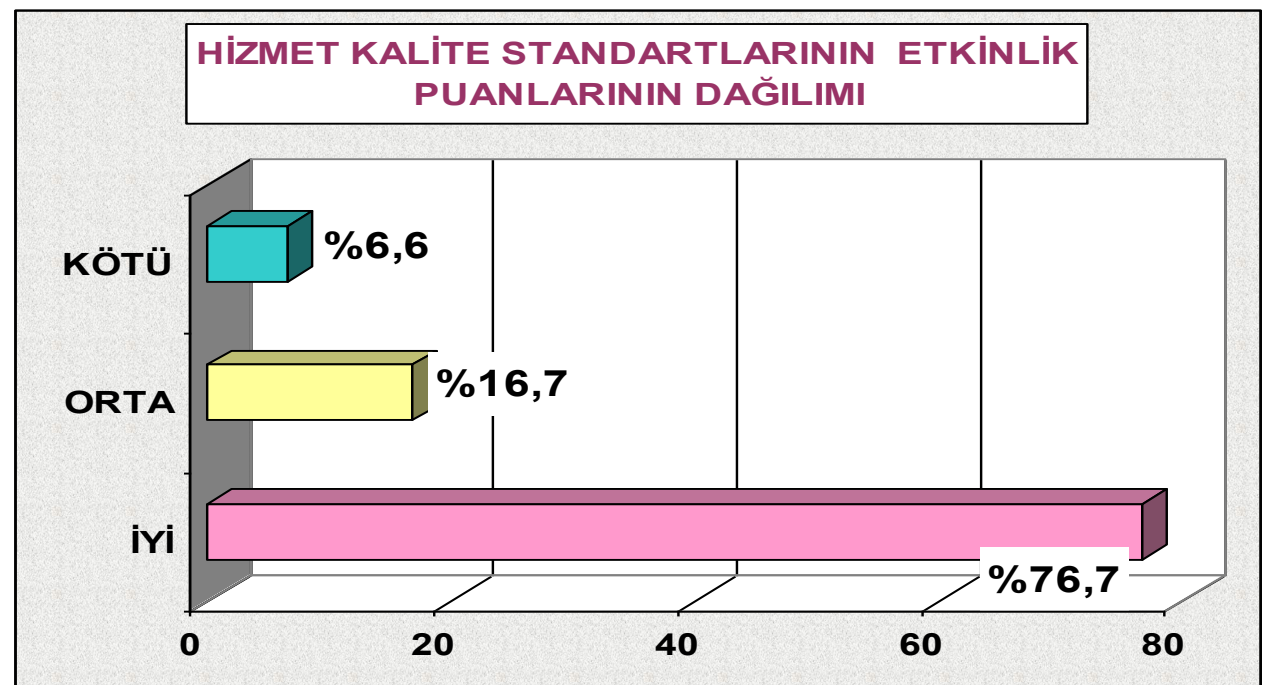

Grafik 3. Katılımcıların HKS'nın etkinliğine yönelik puanlarının dağılımı 


\section{Tartışma}

Sağlık hizmeti sunumu, kişilerin yaşam kalitesini ve mutluluğunu doğrudan etkileyen bir alan olarak görülmelidir. $\mathrm{Bu}$ kapsamda sağlık hizmetlerinin düzeyi, ülkelerin gelişmişlik düzeyinin de bir göstergesi olarak kabul edilmektedir. Hastanelerde kalite çalışmaları, hastanelerin bu fonksiyonlarının gerçekleştirilmesini sağlayan süreçlerle doğrudan ilişkilidir. $\mathrm{Bu}$ süreçler; teşhis, tedavi ve bakım süreçleri ile bunları destekleyen alt süreçlerden oluşmaktadır. ${ }^{8}$ Hizmetlere duyulan gereksinim, kaliteli hizmete olan gereksinimi de beraberinde getirmiştir. İnsanlar, ihtiyaç duydukları hizmetlerin en iyisini almak ve tatmin olmak isterler. $\mathrm{Bu}$ nedenle hizmet üretirken, mutlaka kaliteyi gözetmek gerekmektedir. Ancak ürün kalitesi, fiziksel ve somut değişkenlerle belirlendiği halde, hizmet kalitesini ölçmek zordur. Hizmetin kalitesini ölçen, onu alan insanlardır. Dolayısıyla hizmetin kalitesi, insandan insana değişen bir özellik göstermektedir. Hizmet kalitesinin yükselmesinin ya da verilen hizmetin tatmin edici olmasının anahtarı, o hizmeti alanlardadır. ${ }^{9}$

Sağlık hizmetlerinin bireye ve topluma eldeki en son profesyonel bilginin 1şı̆̆ında ve arzu edilen sağlık sonuçlarına ulaşacak şekilde sunulmasına sağlıkta kalite denir. Sağlık kuruluşları ulusal alanda rekabet ederken, uluslararası alanlardan hasta çekmek için çaba sarf etmektedir. Tüm bu uğraşlar sağlık kuruluşlarını kaliteli hizmet sunma anlayışına itmektedir. ${ }^{10}$

Çalışma, hasta ve çalışan güvenliği temelinde kaliteli hizmet sunma ve hizmetin etkin değerlendirilmesi sürecinde çalışanların görüşlerini belirlemek amacı gerçekleştirilmiştir. Araştırma kapsamına alınan sağlık çalışanlarının \%36.7'sinin 2430 yaş gurubunda yer aldığ $1, \% 80$ 'inin lisans ve üzeri eğitim aldığı, \%33.4'ünün hemşire olduğu, HKS gereğince tüm bölümlerden katılımın sağlandığı belirlenmiştir. Çalışmada katılımcıların daha önce hasta ve çalışan güvenliği konusunda \%83 oranında eğitim aldığ 1 belirlenmiştir. Katılımcıların \%73,6's1 temelde hasta güvenliğini sağlik hizmetlerinin kişilere vereceği zarar1 önlemek ve $\% 70$ oranında çalışan güvenliğini, çalışanlara gelebilecek zararı önlemek olarak tanımladıkları saptanmıştır (Tablo 1). Katılımcılar hasta ve çalışan güvenliğine ait rollerini tanımlarken \%66,6 oranında sürecin tamamında rolleri olduğunu ifade etmişlerdir (Tablo 2).

Kalite eğitimlerinin amacı sadece bilgi ve beceri kazandırmak değildir. Bunun yanında çalışanların yaşam kalitesini geliştirerek çalışma sevgisini artırmaktır. İşini severek yapan çalışanların ürettiği ürünlerin müşteri tatminindeki payı da artacaktır. Kurumlarda uygulanan kalite programları, her seviyedeki çalışanın daha fazla katılım ve sorumluluk almasinı gerektirmektedir. Çalışanların daha fazla sorumluluk almaları için, daha fazla bilgi ve becerilerle donatılması gerekmektedir. Çalışanların iletişim becerileri, grup dinamikleri, istatistik yöntemleri gibi, çok farklı alanlarda kendilerini geliştirilmelerine olanak sağlayacak ortamlar sağlanmalıdır. Bunun karşılanabilmesi için eğitim tüm kalite programlarının temelini oluşturmaktadır. ${ }^{11}$ Sağlık çalışanları hasta tedavi ve bakımının her alanında hasta güvenliği ile iç içe durumdadır. $\mathrm{Bu}$ bağlamda; hasta güvenliğinin savunulması, risk ve riskin azaltılması, istenmeyen olayların rapor edilmesi, tüm çalışanların görevleri arasındadır. ${ }^{8}$

Karaca ve ark. tarafindan hemşirelerin hasta güvenliği kültürü üzerine yönelik yaptıkları çalışmada; hemşirelerin \% \% 76,2'sinin hasta güvenliğiyle ilgili eğitim aldıklarını belirttikleri, eğitim alanlardan \%91,3'ünün alınan bu eğitimleri yeterli gördükleri saptanmıştır. ${ }^{12}$ Blendon ve arkadaşları tarafından sağlık çalışanlarının hasta güvenliği ve tıbbi uygulama hataları konularındaki algilamaları değerlendirilmiştir. Çalışmada elde edilen 
verilere göre, Çalışmaya katılanların $\% 44$ 'ü hasta güvenliği ile ilgili yeterli bilgisi olduğunu belirtmiştir. Bilgilerinin sınırlı olduğunu ifade edenlerin oranı $\% 36$, yetersiz olduğunu belirtenlerin oran1 $\% 20$ ‘dir. Büyük çoğunluk (\%51) konu ile ilgili hiçbir eğitim almadığını bildirirken, gönüllülerin \%17'si yüksek öğrenim sırasında, \%16'sı sürekli eğitim sürecinde ve yine \%16`s1 özel ilgisi nedeni ile kişisel eğitim aldıklarını ifade etmişlerdir. $\mathrm{Bu}$ çalışmada sağlık çalışanlarının hasta güvenliği ile ilgili bilgilerinin sınırlı olduğu ortaya çıkmıştır. Bu konuda yüksek öğrenim sırasında eğitim aldığını belirtenlerin (\%17) büyük çoğunluğu yüksek hemşirelik okulu mezunlarıdır. Tıp fakültelerinde bu konular ile ilgili eğitim bütün dünyada yetersiz kalmaktadır. $\mathrm{Bu}$ çalışmada da hekimlerimizin çoğu hasta güvenliği ile ilgili bilgilerini sürekli eğitim veya kendi kendine eğitim ile elde etmişlerdir. Hasta ve çalışan güvenliği konusunda farkındalığın ve uygulamalar konusunda katılımcılığın arttırılmasında eğitimin önemli bir yeri vardır. Eğitimin örgün eğitim zamanında başlatılıp hastane içi hizmet içi eğitimlerle pekiştirilmesi sürecin etkinliğini daha fazla arttırabilir. ${ }^{13}$ Sonuçlarımızda hasta ve çalışan güvenliği eğitimi alanların oranının $\% 83$ olması ve bu eğitimlerin hastanemizden alınması hasta ve çalışan güvenliği kültürümüzde eğitimin önemli bir yere sahip olduğunun bir göstergesi olmuştur.

Çalışmada katılımcılar daha önce kısmi olarak bulunan ama HKS ile daha da şekillenen hasta güvenliği uygulamalarını 8 başlık altında toplamış ve en fazla $\% 30$ ile kimliklendirmeyi birinci sirada, \%18 ile ilaç güvenliğini ikinci sırada ve $\% 17$ ile enfeksiyon kontrolünü üçüncü sirada belirtmişlerdir (Grafik 1). Katılımcılar çalışan güvenliği uygulamalarını ise 4 başlık altında toplamış ve en fazla \%40 ile sağlık taramalarını birinci sırada, \%30 ile koruyucu ekipmanların teminini ikinci sirada ve $\% 20$ ile enfeksiyon kontrolünü üçüncü sırada belirtmişlerdir (Grafik 2).
Sağlık Bakanlığı, 2011 yılında yayımladığ1 "Hasta ve Çalışan Güvenliğinin Sağlanmasına Dair Yönetmelik" ile sağlik kuruluşlarında hasta ve çalışan güvenliği için güvenli hizmet sunumu ve güvenli bir ortam sağlanmasına, hizmet sunumunda kalitenin artırılmasına, sağlık kurumunda hasta ve çalışanlar için muhtemel risklerin belirlenmesine, bu risklerin giderilmesi için uygun yöntem ve tekniklerin belirlenmesine ve hizmet içi eğitimler ile güvenli hizmet sunumu ve güvenli çalışma ortamının sürdürülebilirliğinin sağlanmasına yönelik usul ve esasları belirlemiştir. ${ }^{5}$ Literatürde hasta güvenliği hedefleri; hasta kimliğinin doğrulanması, sağlık hizmeti sunan ekibin kendi içerisindeki iletişimi, ilaç güvenliği, sağlık bakımıla ilgili enfeksiyonların önlenmesi, tedavide uzlaşma, hastaların düşmesinin önlenmesine yönelik girişimler, cerrahi yanıklar, hasta katılımı, bası yaraları, risk değerlendirme odaklı hizmet sunumu, hastanın durumundaki değişime hızlı yanıt verebilme (hantallıktan uzak yapılanma), anlaşılması zor ya da yanlış anlaşılmaya açık kısaltmalar ve yanlış taraf cerrahisini önlemeye yönelik protokoller gibi çok değişik konulardan oluşmaktadır. Hekimlerin liderliğinde özellikle hasta güvenliği ile ilgili standartların gözden geçirilmesi, hasta güvenliği hedeflerinin belirlenmesi ve beklenmeyen olay bildirimlerinin ele alınması hasta güvenliğ $\mathrm{i}$ alanının izlenmesi ve geliştirilmesi açısından önem taşımaktadır.

$$
\text { Çalışanların hasta güvenliğ }
$$

konusundaki görüşleri içerisinde, hasta güvenliği kriterleri arasında önemli bir yere sahip olan ve risklerin büyük bir çoğunluğunun önlenmesini sağlayan uygulamaları (kimliklendirme, ilaç güvenliği ve hastane enfeksiyonlarını önleme) ilk siralarda ifade etmeleri hasta güvenliği konusunda farkındalığın sağlanması açısından dikkat çekicidir. Sonuçlarımız literatür bilgileri ile paralellik göstermiştir.

Hasta güvenliği kadar çalışan güvenliği de HKS'nin önemli bir 
parçasıdır. Çalışan güvenliği uygulamalarının aynı zamanda hukuki bir boyutu da vardır. Yönetim çalışan güvenliğini ilgilendiren tehlikelerin tespiti ve oluşabilecek zararların azaltılmasına yönelik çalışmaları yapmak zorundadır. ${ }^{15}$ Sadece yönetimin çalışan güvenliği ile ilgili düzenlemeler getirmesi bu konuda istenilenin elde edilmesi için yeterli değildir. Çalışanların da bu sistemi benimsemeleri, hatta doğrudan katılımları gerekir. Çalışanlar, kendi güvenliklerinin sağlanmasında önemli bir role sahiptir. Çalışanlar, görüş ve önerilerini yönetime ileterek, olay bildiriminde bulunarak, memnuniyet anketlerini gerçekçi doldurarak, kayıtların düzgün tutulmasını sağlayarak, sağlık taramalarını takip ederek, eğitimlere katılarak ve yeni eğitim programları önererek hem kendileri için hem de hastalar için daha güvenli ortamlar oluşmasına katkıda bulunabilirler. ${ }^{6}$

Araştırmamızda katılımcıların çalışan güvenliği kriterleri konusunda literatürle uyumlu kriterleri ifade etmeleri, eğitimlere düzenli katılmaları, süreci iyileştirmeye yönelik görüşlerde bulunmaları, güvenlik raporlama uygulamasına aktif katılmaları kendilerini sürecin birer parçası olarak gördüklerinin ve katılımcı bir yaklaşım sergilediklerinin bir göstergesi olmuştur.

Kat1limcilar HKS'nin hasta ve çalışan güvenliğine genel olarak getirilerini, \%66.6 oran1 ile "HKS bölümümüz hasta ve çalışan güvenliği uygulamalarının şekillenmesinde, standartlarının belirlenmesinde ve aktif uygulanmasında faydalı oldu" şeklinde ifade etmişlerdir (Tablo 3).

Çalışmamızda katılımcılar HKS'nın genel olarak değerlendirmesi yapmışlar bölümlerine ait kriterleri baz alarak olumlu ve olumsuz yönlerini ifade etmişlerdir. HKS'nın olumlu yönleri içerisinde \%33 oranı ile "Hasta ve çalışan güvenliği uygulamalarının şekillenmesini ve kullanılmasını sağladı" ilk sırada yer almıştır, bunu standartları oluşturdu, etkin değerlendirme ortamı sağladı, riskleri azaltt1 ifadeleri izlemiştir. Bozkurt ve ark. "Kurumsal Performans Denetimlerinin Eğitim Ve Araştırma Hastanelerinin İyileştirmelerine Etkisi" üzerine yönelik yaptıkları çalışmada; Hastane çalışanları gözüyle, kurumsal performans denetimlerinin kurum üzerine etkileri değerlendirilmiş, sonuçta denetimlerin hastanenin fiziki altyapı ve süreç iyileştirmelerine olumlu katkılar sağladığı, çalışanların katılım ve inançlarının arttırıldığı belirlenmiştir. ${ }^{16}$

Gürcü ve ark. HKS'nin kurum kalitesine sağladığ 1 katkı ile ilgili yöneticilerin görüşlerini aldığ 1 çalışmada, Yöneticilerin HKS uygulamalarının kurum kalitesine oldukça önemli katkı sağladığ 1 konusunda hemfikir olduğu, standartların memnuniyet düzeyini artırdığını, kurumun kendini ölçme ve değerlendirmesine imkân sağladığını, uygulanan anketlerin objektif bir nitelik taşıdığını bildirdikleri belirlenmiştir. HKS uygulamalarının yapılan işleri kolaylaştırdığ çıkmıştır. Diğer bir sonuç kurumlar arası rekabete olumlu katk1 sağladığ yönündedir. ${ }^{17} \mathrm{Bu}$ çalışmada katılımcılar HKS'nın olumsuz yönlerini ilk sırada $\% 34,6$ oranı ile "Benzer ve tekrarlı kayıtların oluşturulması bu nedenle zaman yönetiminde aksama" olarak belirtmişler. Olumsuz yönleri içerisinde ayrıca belirli meslek gruplarının (ağırlıklı hemşireler) denetlenmesi, denetim kriterleri ve denetim süreci ile ilgili geribildirim mekanizmasının yetersiz olması ifadelerine de yer vermişlerdir. (Tablo 4).

Çalışanlar HKS'nin iyileştirilmesi gereken yönleri konusunda, katılımcılar özellikle hizmet kayıtlarında tekrara yol açabilecek alanların daha net ve zaman yönetime uyan şekilde revize edilmesi, kalite denetimleri sirasında kriterlerin değerlendirilmesi aşamasında kurum çalışanlarının tamamının sürece entegre edilmesi ve değerlendirme ekibinin bu konuda hassas davranarak ortak dil oluşturması hususunda önerilerde bulunmuşlardır. Değerlendirmelerin tek meslek grubu (ağırlıklı olarak hemşirelik) üzerinden yürütüldüğü geleneksel 
yaklaşımdan uzak durulması ve değerlendirme süreci sonrası deneyimlenen denetimle ilgili kurum çalışanlarının öneri ve geribildirimlerinin de alındığ bir değerlendirme sürecinin oluşturulması ifade edilen konular arasında yer almıştır.

HKS uygulamalarına yönelik çalışanların eleştirilerinin olması doğaldır. Önemli olan çalışanların bu yöndeki eleştiri, görüş ve önerilerini mevcut uygulamayı geliştirecek şekilde dile getirmesidir. Söz konusu geri bildirimlerin düzenleyiciler tarafından dikkate alınması ile daha iyiye ulaşılması sağlanacaktır. Çalışanların hastane verimliliğinin artırılması yönündeki çalışmalara inançlı ve gönüllü olarak katılımı sağlanmalı, hastane personeli sürekli geliştirme, kalite çemberleri ve eğitim süreçlerinin ayrılmaz parçaları olmalıdırlar.

$$
\text { Sağlık çalışanlarının HKS }
$$

uygulamalarını değerlendirmek için verdikleri puanların dağılımına baktığımızda, $\quad \% 76,7 \quad$ oranıyla uygulamaların etkinliğinin iyi olarak nitelendirildiği ve uygulamalara ait memnuniyetlerinin iyi olduğu belirlenmiştir (Grafik 3). Çakır ve Tütüncü tarafindan İzmir ili hastanelerinde hasta güvenliği algısı ile ilgili kamuya bağlı altı hastanede çalışan 803 kişi ile yapılan çalışmada, katılımcıların \%46.3'ü çalıştıkları hastanede hasta güvenliğinin iyi olduğunu, \%31.1'i ne iyi ne kötü olduğunu ve \%22.4'ü ise kötü olduğunu belirtmişlerdir. ${ }^{14}$ Tansüyer' in Malatya ${ }^{\text {ee }} \mathrm{da}$ bir üniversite hastanesinde yaptığ 1 çalışmada, sağlık personelinin $\% 17,3^{\mathrm{e}} \mathrm{ü}$ hasta güvenliği derecesini mükemmel, \%

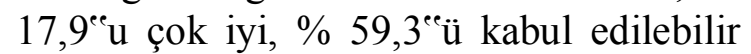
bulurken $\% 4,6^{\text {ee }}$ s1 zayıf, $\% 0,9^{\text {ee }}$ u başarısız bulmuştur. ${ }^{18}$ Çakır'ın İzmir'de yaptığı bir çalışmada hasta güvenliği derecesi ISO 9001:2000 belgesine sahip hastane çalışanlarında 3,92 ile çok iyi ve kabul edilebilir arasında bir değer çıkarken, bu belgeye sahip olmayan hastanelerde 2,75 ile kabul edilebilir ve zayıf arasında çıkmıştır. ${ }^{19}$ Karaboğa ve Bahçecik eğitim ve araştırma hastanelerindeki çalışmalarında, hemşirelerin \%48,7'si birimlerini hasta güvenliği derecesi konusunda kabul edilebilir; özel hastanelerdeki hemşirelerin \%51'i çok iyi bulduğu, hemşirelerin hasta güvenliğ $i$ kültürü algılamalarının orta düzeyde olduğunu belirledi. ${ }^{20}$

Hasta güvenliği kültürünün yerleştirilebilmesi ve iyileştirilebilmesi için tüm çalışanların hasta güvenliği ile ilgili alg1 ve tutumlarının ölçülmesi (kültür surveyi) ve bu ölçümlerin aralıklarla tekrar yapılması önerilmektedir. ${ }^{10}$ Ölçümlerden elde edilen sonuçlar, yönetici ve liderlere, hasta güvenliği ile ilgili çalışanların kaygıları ve kalite ile ilgili iyileştirme yapılacak alanları belirlemede çok yararlı bilgiler vermektedir. Ayrıca, bu sonuçlar diğer kurumlarla yapilacak karşılaştırmalarda da kullanılabilir. ${ }^{21}$

Singla ve arkadaşları tarafindan hasta güvenliği kültürü ölçmeye yönelik araçların irdelendiği çalışmada, 13 tane ölçme aracı değerlendirilmiş; bu araçların her birinin içerik, soru sayısı, araç geliştirme süreci ve uygulama yapılacak hedef kitle yönünden farklılıklar gösterdiği belirtilmiştir. Bundan başka, bu ölçme araçlarında bazı sınırlılıkların olduğu ve konu ile ilgili daha fazla çalışmalara gereksinim olduğu bildirilmiştir. ${ }^{22}$ Konu ile ilgili ulusal literatür tarandığında ise hasta güvenliği kültürü ile ilgili gerçek çıktıları öngörmede veya sonuçları en iyi şekilde analiz etme ve yorumlamada sınırlı sayıda çalışmaya rastlanmıştır.

\section{Sonuç ve Öneriler}

$\mathrm{Bu}$ çalışma sonucunda;

$\checkmark$ Katılımciların daha önce hasta ve çalışan güvenliği konusunda $\% 83$ oranında eğitim aldığ 1 , HKS'yi uygun ve sürekli iyileşmeyi sağladığı için gerekli gördükleri,

$\checkmark$ Katılımcıların daha önce kısmi olarak bulunan ama HKS ile daha da şekillenen hasta güvenliğ $i$ uygulamalarını 8 başlık altında topladikları ve en fazla $\% 30$ ile 
kimliklendirmeye birinci sirada yer verdikleri,

$\checkmark$ Katılımcıların daha önce kısmi olarak bulunan ama HKS ile daha da şekillenen çalışan güvenliği uygulamalarını 4 başlık altında topladıkları ve en fazla \%40 ile sağlık taramalarını birinci sırada belirtikleri,

$\checkmark$ HKS'nın olumlu yönleri içerisinde $\% 33$ oranı ile "Hasta ve çalışan güvenliği uygulamalarının şekillenmesini ve kullanılmasını sağladı" ibaresine ilk sırada yer verdikleri,

$\checkmark$ HKS'nın olumsuz yönleri içerisinde ise $\% 34,6$ oranı ile "Benzer ve tekrarlı kayıtların oluşturulması bu nedenle zaman yönetiminde aksama" ibaresine ilk sirada yer verdikleri,

$\checkmark$ Sağlık çalışanlarının HKS uygulamalarını değerlendirmek için verdikleri puanların dağılımına baktığımızda, $\quad \% 76,7 \quad$ oranıyla uygulamaların etkinliğinin iyi olarak nitelendirildiği ve uygulamalara ait memnuniyetlerinin iyi olduğu belirlenmiştir. Araştırmada, sağlık çalışanlarının HKS konusunda bilgi seviyelerinin yeterli olduğu saptanmıştır.

$\mathrm{Bu}$ değerlendirmelerin 1şı̆̆ında hastanelerde hasta ve çalışan güvenliğ $i$ kültürünü oluşturmak ve standartların etkinliğini arttırmak için bazı öneriler geliştirilmiştir.

$\checkmark$ Tüm çalışanların hizmet standartları, hasta ve çalışan güvenliği konusunda sürekli eğitilmesi,

$\checkmark$ Her hastanenin kalite yol planı hazırlamas1 ve uygulaması,

$\checkmark$ Sağlık çalışanlarının değerlendirme ve standartlara yönelik eleştiri, görüş ve önerilerini mevcut uygulamay1 geliştirecek şekilde dile getirmesinin sağlanması,

$\checkmark$ Söz konusu geri bildirimlerin düzenleyiciler tarafindan dikkate alınması ile daha iyiye ulaşılmasının sağlanması,

$\checkmark$ Sağlık çalışanlarının kalite yönetimi felsefesine inançlı ve gönüllü olarak katılımının sağlanması,

$\checkmark$ HKS'nın iyileştirme sürecinde değerlendirmeye yönelik kapsamlı çalışmaların yapılması önerilir.

\section{Kaynaklar}

1. Bal A, Çalış A, Tosun F, Yılmaz H, Memiş R, Yıldız A. ve Ark., Giresun Prof. Dr. A. İlhan Özdemir Eğitim Ve Araştırma Hastanesinde Çalışanların Hasta Güvenliği Algısı. II. Uluslararası Sağlikta Performans Ve Kalite Kongresi Kitab1.; 2010;1:551-563.

2. Fener S, Kahraman B, Şengül H, Semiz MM, Taşkın Eğici M. "Kurumsal Performans Denetimlerinin Eğitim Ve Araştırma Hastanelerinin İyileştirmelerine Etkisi” III. Uluslararası Sağlikta Performans Ve Kalite Kongresi Sözel Bildiriler Kitab1, Ankara, 2011;132-145.

3. Vangeest JB, Cummins DS. An Educational Needs Assessment For İmproving Patient Safety: Results Of A National Study Of Physicians And Nurses, National Patient Safety Foundation. White Paper Report 3, 2003.

4. Tedavi Hizmetleri Genel Müdürlüğü Performans Yönetimi ve Kalite Geliştirme Daire Başkanlığı, Hastane Hizmet Kalite Standartları Kitabı, Pozitif Matbaa Ltd. Şti. Ankara,2011;3-5.

5. T.C. Sağlık Bakanlı̆̆ı, Hasta ve Çalışan Güvenliğinin Sağlanmasına Dair Yönetmelik, Ankara, 2011.

6. İşlek, E. Bir Özel Dal Eğitim ve Araştırma Hastanesinde Hasta Güvenliğini Tehdit Eden Olayların ve Olası Nedenlerinin Tanımlanması, Sağlık Yönetimi 
Ana Bilim Dalı Yüksek Lisans Tezi, 2009; 1-8.

7. Uğurluoğlu Ö, Çelik Y. Sağlık Sistemleri Performans Ölçümü, Önemi ve Dünya Sağlık Örgütü Yaklaşımı, Hacettepe Sağlık İdaresi Dergisi, 2005; 8-1, s. 3-29.

8. Kavuncubaşı Ş, Esatoğlu A. Sağlık Hizmetlerinin Kalitesinin Hemşirelik Hizmetleri Açısından Değerlendirilmesi, Hemşirelik ve Ebelik Eğitimi ve Uygulamalarında Toplam Kalite Yönetimi, Erciyes Üniversitesi Yayınları, 1998; 1112.

9. Karahan K. Hizmet Pazarlaması, Beta Yayın Dağıtım A.Ş. İstanbul:2006; s.38.

10. Akalın E. Hasta Güvenliği Kültürü: Nasıl Geliştirebiliriz? Ankem Dergisi, 2004; 18: s.12-13.

11. Altınok M. Toplam Kalite Yönetimi İlkeleri Çerçevesinde İşletmelerde Eğitim İhtiyaçları Tespiti ve Uygulamalı Bir Örnek. Balıkesir Üniversitesi İşletme ABD. Yüksek Lisans Tezi. Balıkesir, 2005; 21-25.

12. Karaca A, Arslan H. Hemşirelik Hizmetlerinde Hasta Güvenliği Kültürünün Değerlendirilmesine Yönelik Bir Çalışma, SHYD. 2014; s. 9-18.

13. Blendon RJ, Desroches CM, Brodie $M$, et al. Views of Practicing Physicians And The Public On Medical Errors, N Engl J Med, 2002; 347:1933-40.

14. Çakır A, Tütüncü Ö. İzmir İli Hastanelerinde Hasta Güvenliği Algısı. II. Uluslar Arası Sağlıkta Performans ve Kalite Kongresi Bildiri Kitab1, Antalya, 2010; 2, s.189-204.

15. Hakeri H. Sağlık Çalışanı Güvenliği ve Hukuksal Sorumluluk, Sağllkta Performans ve Kalite Dergisi, 2010; 1 : s. 53-59.

16. Bozkurt İ. Halil Şengül H, Orman H, Katırcı Fener S, Kahraman B, Taşkın Eğici M. 2006 Yllından İtibaren Hizmet Kalite Standartlarının Kamu Hastanelerine Etkisi, III. Uluslararas1 Sağlıkta Performans ve Kalite
Kongresi, Sözel Bildiriler Kitabı, Ankara, 2011; s.162-176.

17. Gürcü M, Baştürk F, Ömer Yıldız Ö. Yozgat İli Hizmet Kalite Standartlarının Etkinliği ve Kalite Çalışmalarıyla İlgili Hastane Yöneticilerinin Değerlendirmeleri, III. Uluslararası Sağlikta Performans Ve Kalite Kongresi Sözel Bildiriler Kitab1, Ankara, 2011; s.145-162.

18. Tansüyer T. Hasta Güvenliği ve Tibbi Hatalar Konusunda Sağlık Personelinin Görüşlerini Belirlemeye Yönelik Bir Alan Araştırması. Yüksek Lisans Tezi, Gazi Üniversitesi, Ankara, 2010; 15-17.

19. Çakır A. Hasta Güvenliği Kültürü İle Kalite Yönetim Sistemi Arasındaki İlişkinin Analizi. Yüksek Lisans Tezi, Dokuz Eylül Üniversitesi, İzmir, (2007);36-37.

20. Karaboğa Gündoğdu S, Bahçecik N. Hemşirelerde Hasta Güvenliği Kültürü Algılamasinın Belirlenmesi, Anadolu Hemşirelik ve Sağlık Bilimleri Dergisi, 2012; 15-2.

21. Kocaman G. Hemşirelik Hizmetlerinde Hasta Güvenliği-Uluslararas1 Hemşirelik Konseyi ICN, İzmir, 2007; s.30.

22. Gökdoğan F, Yorgun S. Sağlık Hizmetlerinde Hasta Güvenliği ve Hemşireler, Anadolu Hemşirelik ve Sağlık Bilimleri Dergisi, 2010; 13(2):53-59. 